Article

\title{
Lanthanides and Actinides in Humic Acids of Soils and Paleosols of Forest-Steppe Conditions in the Southern Urals
}

\author{
Maria Dergacheva ${ }^{1, *}$, Olga Nekrasova $^{2}$, Leonid Rikhvanov ${ }^{3}$ and Dmitry Zdanovich ${ }^{4}$ \\ 1 Laboratory of Biogeocenology, Institute of Soil Science and Agrochemistry of Siberian Branch of Russian \\ Academy of Sciences, Novosibirsk 630000, Russia \\ 2 Institute of Natural Sciences and Mathematics, Ural Federal University named after the First President of \\ Russia BN Yeltsin, Ekaterinburg 620000, Russia; o_nekr@mail.ru \\ 3 Department of Geology, Institute of Natural Resources, Tomsk Polytechnic University, Tomsk 634000, Russia; \\ rikhvanov@tpu.ru \\ 4 Scientific and Educational Center for Research on the Problems of Nature and Man, Chelyabinsk State \\ University, Chelyabinsk 454000, Russia; Dgz74@yandex.ru \\ * Correspondence: mid555@yandex.com or mid555@yandex.ru; Tel.: +7-913-895-5905
}

Received: 19 January 2018; Accepted: 6 March 2018; Published: 13 March 2018

\begin{abstract}
This article analyzes the lanthanum, cerium, samarium, europium, terbium, ytterbium, lutetium, uranium, and thorium content in humic acids within soil and paleosol surface horizons from the southern steppe in the Southern Urals. Research demonstrates similar accumulation levels of these elements in paleosols isolated from both the active medium between 3.6 and 3.3 thousand years ago and in recent background soils. Despite the lack of significant differences, research has shown a growing content among the rarest metals in the series "the buried paleosols-man-modified paleosols of settlement-recent background soils". Research has detected the lowest content of $\mathrm{La}, \mathrm{Ce}, \mathrm{Sm}, \mathrm{Eu}$, $\mathrm{Yb}, \mathrm{Lu}$, and Th in preparations of humic acids of recent background soils. This reveals a close content to most elements in humic acids of paleosols buried under barrows and ancient settlement paleosols. Additionally, it indicates the virtual absence of anthropogenic impact on binding lanthanides and actinides by humic acids in ancient times. The contribution of humic acids into the common pool for each element was evaluated using a special approach. Research showed that there was less than half the share of elements associated by humic acids of paleosols than in the recent background chernozems in the total pool of lanthanides and actinides. This article considers the prospects of using humic acids of recent and ancient soils in identifying behavioral patterns of metal complexes through time.
\end{abstract}

Keywords: humic acids; lanthanides; actinides; paleosols; recent background soil; forest-steppe; Southern Urals

\section{Introduction}

Humic acids (HAs) are natural substances that perform several functions in the biosphere, most notably acting as stabilizing forces [1,2]. One of a humic acid's functions is that of protection. The growth of productive human activity had led to an increase in biosphere pollution through toxic elements; however, humic acids can neutralize toxic effects on organisms and ecosystems as a whole. This is due to HA's ability to accumulate, deposit, and store carbon, along with a wide range of trace elements for long geological periods, as well as the ability to inhibit chemical compounds that are toxic to living organisms. This ability of humic acids is well known [3-7].

Humic acids belong to a class of natural substances with variable composition. The content of their structure-forming elements varies per the following ranges (wt \%): carbon between 50 and 62; hydrogen between 2.8 and 6.0; oxygen between 31 and 40; and nitrogen between two and six. 
Humic acids are polyampholytes which comprise several functional groups that can interact with metal ions to form metal-humic complexes $[6,8,9]$. Their effects on metal mobility in soil and their availability to plants is widely known [4,9-12].

This peculiarity of humic acid causes the demand for information on their ability to form compounds with different chemical elements, including lanthanides and actinides. Therefore, humic acid attracts the attention of researchers who consider them as potentially effective remediators or as tools to enhance other remediating action [3,11,13-15].

Although scholarly interest in these elements in various environmental media (soils, peat, sediments, etc.) has increased substantially in the last two to three decades, information about lanthanide and actinide content in natural humic acids is scant. This is a result of the amount of growth of lanthanides and actinides in the environment, which is associated primarily with nuclear tests from the mid-twentieth century and the development of nuclear fuel [16]. Currently, lanthanides are used in nanotechnology [17-20] and in the exploration for mineral resources in which they are introduced into the environment through industrial waste. Demand for lanthanides is constantly increasing, particularly as part of commonly used phosphate and humic fertilizers, which provide an alternate means for their entrance into the environment [21,22].

Actinides have long been recognized as hazardous to human health. The toxicity of lanthanides has been equally well documented [23-25].

In connection to active investigations of humic acids for use in the remediation of contaminated soils $[11,12,14,26]$ as well as the application of humic acids in agriculture as growth stimulators and fertilizers [27-31], the question arises as to levels of lanthanide and actinide in humic acids, specifically, their share in the total soil element pool. Such questions are important as such information is virtually absent. Additionally, the ability of humic acids not only to accumulate but to preserve lanthanides and actinides for long geological periods may result in negative impacts on the environment.

The aim of this study is to present the quantitative characteristics of lanthanide and actinide content in humic acids of paleosols and recent soils in the southern forest-steppe zone of the Southern Urals and to indicate the tendency of their changes in recent time compared to the period 3.6-3.3 thousand years ago.

\section{Materials and Method}

Humic acids were isolated and analyzed from the upper humus (A) horizons of soils and paleosols under barrows and paleosols from man-made settlements (the so-called cultural layer) [32,33]. These soils were developed under forest-steppe conditions in the Southern Urals (Figure 1).

The area under study is located in the Plastovsky district, Chelyabinsk region, a kilometer northwest of the village Stepnoe. The territory is confined to the first terrace of the left bank of the Uy River. According to climatic zoning, the key area is in the minimally humid, warm, southern region of continental West Siberia [34]. It is characterized by an average annual air temperature of about $+2{ }^{\circ} \mathrm{C}$, with a sum of temperatures above $10^{\circ} \mathrm{C}$ in the range of $1950-2000{ }^{\circ} \mathrm{C}$. Annual rainfall is approximately $450 \mathrm{~mm}$ with an evaporation $100 \mathrm{~mm}$ higher than the abovementioned value [35]. Vegetation is mainly a combination of birch groves and island pine forests with meadow and forb-grass steppe [36].

Recent soil covers the basic background of the territory (over 30\%) and comprises leached chernozem according to the classification WRB 2014-Haplic Chernozems [37].

The area includes Stepnoe, an archaeological site excavated by Kupriyanova and Zdanovich [38]. The site includes a series of Bronze Age burial barrows with paleosols buried underneath, along with several settlements of a similar age. Thus, the site's paleosols experienced anthropogenic impact, i.e., the effect of people inhabiting them. Both paleosol groups are relatively close in time, within 3.7-3.3 ka BP $[38,39]$. Paleosols were isolated from the surface and from the period's active biological cycle. The ecological situation in the study area is overall favorable as harmful production is absent. 


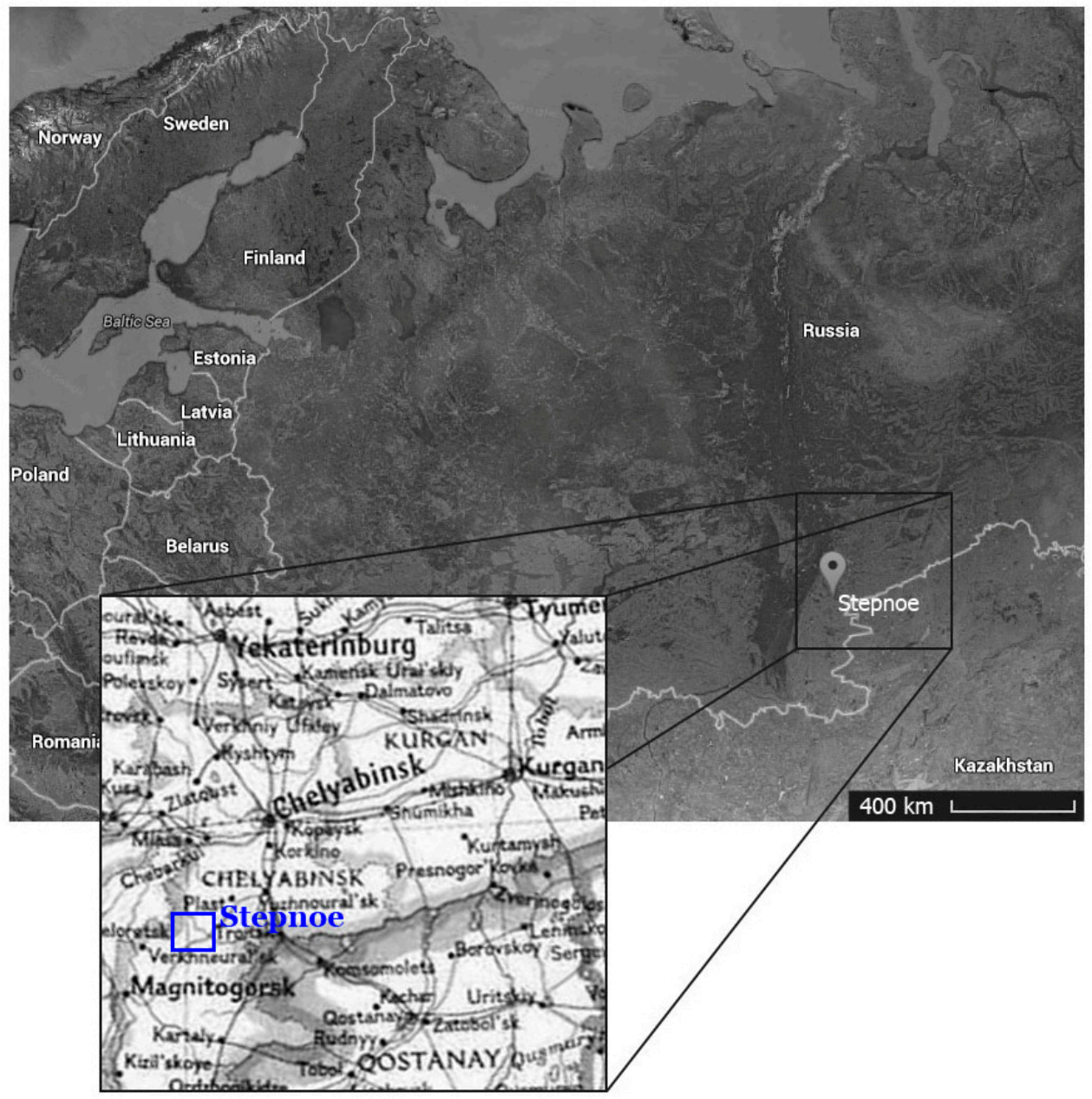

Figure 1. Location of the study area.

Characteristics of humus horizons of paleosols buried under barrows, settlement paleosols, and the recent background soils and humic acids from which they were isolated are represented in Table 1.

According to their morphological characteristics, the area's background soils correspond to leached chernozems. They have a slightly alkaline medium in the humus chernic horizon, containing an average of about $3.2 \%$ of organic carbon and have a humate composition of humus of which about $50 \%$ are humic acids (Table 1 ). The latter have a composition typical for soils formed under forest-steppe conditions (wt \%), carbon: $50.5 \pm 3.4 \%$; hydrogen: $4.2 \pm 0.3 \%$; oxygen: $41.5 \pm 2.9 \%$; and nitrogen: $3.3 \pm 0.3 \%$. The atomic ratio of the basic structure-forming elements, hydrogen and carbon $(\mathrm{H}: \mathrm{C})$, varies in humic acids of leached chernozems in the range of 0.79-1.01 with an average of 0.90 .

Table 1. Characteristics of humus horizons of soils, paleosols, and humic acids (HAs) isolated from them.

\begin{tabular}{cccc}
\hline \multirow{2}{*}{ Characteristics } & \multicolumn{3}{c}{ Objects of Extracting HA } \\
\cline { 2 - 4 } & Recent Background Soils & Paleosols under Barrows & Paleosols of Settlement \\
\hline Thickness, cm & $13-15$ & $20-23$ & $10-12$ \\
pH H2O & $7.1-7.2$ & $7.2-7.3$ & $6.7-7.3$ \\
$x 10^{-6}$ SGSE/g & $2.3-3.5$ & $2.6-3.3$ & $2.4-4.4$ \\
TOC, $\%$ & $2.0-4.5$ & $0.4-0.7$ & $0.4-1.1$ \\
HA, $\%$ & 49 & 51 & 55 \\
CHA $_{\text {FA }}$ & 2.5 & 2.6 & 2.6 \\
C in HA, wt $\%$ & 50.5 & 52.4 & 53.5 \\
H:C in HA & $0.79-1.01$ & $0.87-1.03$ & $0.68-0.83$ \\
\hline
\end{tabular}


According to Zdanovich [38,39] and archaeological findings, the under barrow paleosols with a humus (A) horizon of $22 \mathrm{~cm}$ average thickness were buried about 3600 years BP, whereas the settlement paleosols with thicknesses of about 10-12 cm experienced anthropogenic impact 3300 years BP.

The humus horizons of paleosols under barrows had a slightly alkaline reaction medium, contained $0.4-0.7 \%$ carbon, and were characterized by a humate humus type in which $40-45 \%$ were humic acids. This soil component contained an average of $53.4 \%$ by weight of carbon, similar to the previous atomic ratio of $\mathrm{H}: \mathrm{C}$, which lies within the range typical for soils from both the northern steppe and southern forest-steppe (Table 1).

Settlement paleosols, which experienced anthropogenic transformation in the period of human habitation, were relatively heterogeneous in terms of the characteristics associated with the top 10-12 cm layer, which is known as the "cultural layer" in archaeological science. This is characterized by fluctuations around a neutral reaction of medium, deviating in different samples in one direction or another. Carbon content varied within $0.4-1.1 \mathrm{wt} \%$, averaging $0.7 \%$. The humus had a humate type close to the aforementioned paleosol $\left(\mathrm{C}_{\mathrm{HA}}: \mathrm{C}_{\mathrm{FA}}=2.60\right)$. Humic acid content was slightly more than $50 \%$ (see Table 1); carbon content had an average of $53.5 \mathrm{wt} \%$ with the value of $\mathrm{H}: \mathrm{C}$ in the range of 0.68-0.83 which is typical for chernozem row soils $[40,41]$.

Conclusions were formed according to the rules and principles of the pedohumus method of paleoenvironment diagnostic and reconstruction. This methodology derives from a humus substance's ability to reflect its environment in its composition and properties, preserving this information for a long geological time [42-44]. In addition to information taken from soil samples isolated from humic acid characteristics (Table 1), our results indicate that both recent and ancient soils had been formed in similar temperature conditions with different humidity levels.

Sampling of paleosol humus horizons was done every $50 \mathrm{~cm}$ along the archaeological excavations (Figure 2).

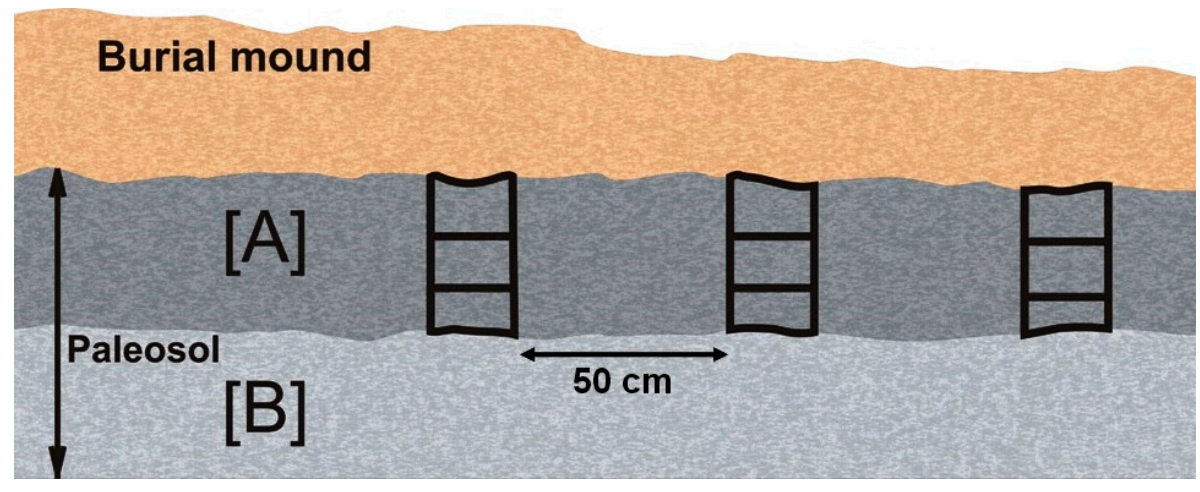

Figure 2. The scheme of paleosol humus horizon sampling.

In frames of genetic horizons depth, soil sampling occurred as a continuous column every 5-10 cm (or less). Samples of recent background soils were taken from sections located around the archaeological site using the same techniques.

The total organic carbon was determined by oxidation with $\mathrm{K}_{2} \mathrm{Cr}_{2} \mathrm{O}_{7}$ (Tyurin's method) [45], humus composition by separate extracting with $\mathrm{NaOH}$ and $\mathrm{H}_{2} \mathrm{SO}_{4}$ (Ponomareva-Plotnikova method) [46].

Humic acids were extracted in strictly identical conditions; they were precipitated by $2 \mathrm{n} \mathrm{HCl}$ from $0,1 \mathrm{n} \mathrm{NaOH}$ extraction after preliminary decalcification of the humus horizon sample. Traditional hard cleaning of humic acid preparations with $6 \mathrm{n} \mathrm{HCl}$ or $\mathrm{HF}+\mathrm{HCl}$ was not carried out. Elemental composition of HA was determined by an analyzer EURO EA-3000 (EuroVector, Pavia, Italy).

Total contents of $\mathrm{La}, \mathrm{Ce}, \mathrm{Nd}, \mathrm{Sm}, \mathrm{Eu}, \mathrm{Tb}, \mathrm{Yb}, \mathrm{Lu}, \mathrm{Th}$, and $\mathrm{U}$ were quantified in humic acids and soils with a technique of multi-element neutron-activation analysis in the laboratory of Tomsk 
Polytechnic University through the application of certified methodologies. Analysis accuracy was checked by standards including the International Standard of sea deposits.

The lanthanides and actinides were determined in both the soil mass and the humic acid preparation masses.

The content of each studied element in the humic acid preparations was recalculated per unit of found carbon, content of total organic carbon in soil, and carbon attributable to humic acid.

Calculations were carried out according to the formula:

$$
\mathrm{a}=\mathrm{b} \cdot \mathrm{c} \cdot \mathrm{d} / \mathrm{f} \cdot 100
$$

where $\mathrm{a}$ is element content in soil HA, $\mathrm{mg} \cdot \mathrm{kg}^{-1}$; $\mathrm{b}$ is Total Organic Carbon (TOC), \%; $\mathrm{c}$ is HA, \%; $\mathrm{d}$ is element content in preparation, $\mathrm{mg} \cdot \mathrm{kg}^{-1}$; $\mathrm{f}$ is $\mathrm{C}$ in $\mathrm{HA}, \mathrm{wt} \%$.

To determine the humic acid participation in the formation of the gross amount of the corresponding element in the soil, this index was recalculated to reflect its content in the whole soil.

In order to recalculate any element in the preparation of humic acid on its content in the soil, it is necessary to have data on the following: the study of the elemental composition of preparation; equity participation of humic acids in the humus composition in the soil; and the total contents of organic carbon and of the studied element in the soil.

\section{Results and Discussion}

To represent the share of lanthanides and actinides associated with humic acids in the total gross content of elements in recent soils and paleosols within the investigated local forest-steppe typical site, it is necessary to consider three problems:

- $\quad$ the content of lanthanides and actinides in the soil mass marked above natural objects (recent background soils and paleosols buried under barrows and the spread on the territory of settlement 3.6-3.3 Ka);

- $\quad$ the content of these elements in preparations of humic acids extracted from the abovementioned soils and paleosols;

- $\quad$ the participation share of each element associated with humic acids in the total pool of recent background soils and paleosols.

The data of lanthanum, lanthanides, and actinides content in recent background soil and paleosols, from which the humic acids have been extracted to determine the amount of these elements present, are presented in Table 2 .

Analysis showed that the greatest values in the humus horizons of recent leached chernozems, paleosols under burial mounds, and anthropogenically modified paleosols of settlement were that of cerium content, constituting an average of $23-37 \mathrm{mg} \cdot \mathrm{kg}^{-1}$. Maximum values exceeding $40 \mathrm{mg} \cdot \mathrm{kg}^{-1}$ in 24 definitions were found only in three cases, the minimum (fewer than $20 \mathrm{mg} \cdot \mathrm{kg}^{-1}$ ) in two. The amount of cerium increased from the paleosols under burial mounds to the anthropogenically modified paleosols of settlement and recent background soils of the study area. As the soils had similar properties, it is likely that an increase in the presence of cerium in the soil mass of recent chernozem captured the growing contamination of the territory by this toxic element. Among the other elements, only lanthanum was characterized by relatively high values of approximately $10 \mathrm{mg} \cdot \mathrm{kg}^{-1}$, while the average quantity in the other various studied objects was similar (Table 2). An increase of lanthanum content from ancient to recent times is seen clearly in the data trends (Figure 3). Lanthanum had smaller gradations of variation than cerium. The minimum value of its content did not fall below 7-10 $\mathrm{mg} \cdot \mathrm{kg}^{-1}$ and the maximum did not exceed $12.6-16.9 \mathrm{mg} \cdot \mathrm{kg}^{-1}$, with the exception of only three cases out of 24 . 
Table 2. The content of some lanthanides and actinides in the humus horizons of paleosols and recent soils of the forest-steppe zone of the Southern Urals in the earth's crust [47] and the biosphere [48], $\mathrm{mg} \cdot \mathrm{kg}^{-1}$.

\begin{tabular}{|c|c|c|c|c|c|c|c|c|c|c|}
\hline Section & Depth (cm) & La & $\mathrm{Ce}$ & Sm & Eu & $\mathrm{Tb}$ & $\mathbf{Y b}$ & Lu & $\mathrm{U}$ & Th \\
\hline \multicolumn{11}{|c|}{ Paleosols under barrows } \\
\hline \multirow[t]{3}{*}{3} & $0-7$ & 11.2 & 27.9 & 2.13 & 0.61 & 0.18 & 1.22 & 0.17 & 2.43 & 2.35 \\
\hline & $7-14$ & 9.4 & 25.4 & 1.93 & 0.60 & 0.29 & 1.05 & 0.14 & 1.77 & 2.01 \\
\hline & $14-21$ & 8.8 & 20.3 & 1.73 & 0.52 & 0.18 & 1.04 & 0.14 & 1.53 & 1.95 \\
\hline \multirow[t]{3}{*}{4} & $0-7$ & 7.7 & 50.5 & 1.39 & 0.47 & 0.17 & 1.01 & 0.13 & 1.11 & 1.55 \\
\hline & $7-14$ & 10.3 & 24.9 & 2.03 & 0.48 & 0.23 & 1.13 & 0.15 & 2.24 & 2.07 \\
\hline & $14-23$ & 7.1 & 22.9 & 2.76 & 0.66 & 0.26 & 1.06 & 0.13 & 2.01 & 1.67 \\
\hline \multirow[t]{3}{*}{6} & $0-7$ & 9.8 & 22.9 & 1.84 & 0.51 & 0.24 & 1.11 & 0.15 & 2.07 & 2.30 \\
\hline & $7-14$ & 10.3 & 24.6 & 1.81 & 0.58 & 0.27 & 1.19 & 0.16 & 1.75 & 2.31 \\
\hline & $14-21$ & 7.7 & 18.1 & 1.52 & 0.48 & 0.24 & 0.99 & 0.12 & 1.03 & 1.64 \\
\hline \multirow[t]{3}{*}{8} & $0-7$ & 10.6 & 27.8 & 1.89 & 0.54 & 0.25 & 1.12 & 0.15 & 2.29 & 2.39 \\
\hline & $7-14$ & 7.7 & 17.6 & 1.35 & 0.54 & 0.22 & 0.91 & 0.12 & 1.69 & 1.72 \\
\hline & $14-22$ & 7.1 & 16.9 & 1.25 & 0.55 & 0.16 & 0.89 & 0.11 & 1.30 & 1.70 \\
\hline Average $(n=12)$ & & $9.0 \pm 1.5$ & $22.7 \pm 4.0$ & $1.80 \pm 0.41$ & $0.55 \pm 0.06$ & $0.22 \pm 0.04$ & $1.06 \pm 0.10$ & $0.14 \pm 0.02$ & $1.77 \pm 0.44$ & $1.97 \pm 0.30$ \\
\hline \multicolumn{11}{|c|}{ Paleosols of settlement } \\
\hline G3-1 & $0-10$ & 9.4 & 23.0 & 1.76 & 0.54 & 0.17 & 1.04 & 0.14 & 2.32 & 2.18 \\
\hline G3-2 & $0-12$ & 8.4 & 21.6 & 1.60 & 0.52 & 0.27 & 1.06 & 0.12 & 2.27 & 2.89 \\
\hline G4-1 & $0-11$ & 9.8 & 25.3 & 1.67 & 0.49 & 0.18 & 1.04 & 0.14 & 2.37 & 2.23 \\
\hline G4-2 & $0-11$ & 8.5 & 29.8 & 2.07 & 0.60 & 0.33 & 1.10 & 0.15 & 2.05 & 2.26 \\
\hline B6-1 & $0-10$ & 8.8 & 20.8 & 1.48 & 0.52 & 0.23 & 1.00 & 0.13 & 1.11 & 2.07 \\
\hline B6-2 & $0-12$ & 16.9 & 37.3 & 2.18 & 0.73 & 0.28 & 1.22 & 0.15 & 1.67 & 2.40 \\
\hline Average $(n=6)$ & & $10.3 \pm 3.3$ & $26.3 \pm 6.3$ & $1.79 \pm 0.27$ & $0.57 \pm 0.09$ & $0.24 \pm 0.06$ & $1.08 \pm 0.08$ & $0.14 \pm 0.01$ & $1.97 \pm 0.45$ & $2.34 \pm 0.27$ \\
\hline \multicolumn{11}{|c|}{ Recent background soils } \\
\hline \multirow[t]{3}{*}{$1-03$} & $0-2$ & 13.6 & 28.9 & 2.27 & 0.62 & 0.32 & 1.18 & 0.15 & 1.80 & 3.07 \\
\hline & $2-10$ & 11.7 & 68.4 & 2.99 & 0.71 & 0.27 & 1.45 & 0.16 & 1.77 & 2.42 \\
\hline & 10-15 & 9.7 & 24.9 & 1.58 & 0.51 & 0.20 & 1.09 & 0.15 & 2.18 & 2.43 \\
\hline \multirow[t]{2}{*}{ 3-03 } & $2-7$ & 10.4 & 29.1 & 2.14 & 0.55 & 0.49 & 1.24 & 0.17 & 1.90 & 2.50 \\
\hline & $7-12$ & 12.6 & 30.9 & 1.96 & 0.61 & 0.48 & 1.12 & 0.15 & 1.98 & 2.54 \\
\hline 8-03 & $2-10$ & 10.0 & 42.7 & 3.51 & 0.78 & 0.49 & 0.97 & 0.15 & 2.10 & 2.85 \\
\hline Average $(n=6)$ & & $11.3 \pm 1.6$ & $37.5 \pm 16.3$ & $2.41 \pm 0.71$ & $0.63 \pm 0.10$ & $0.38 \pm 0.13$ & $1.18 \pm 0.16$ & $0.16 \pm 0.01$ & $1.96 \pm 0.16$ & $2.64 \pm 0.26$ \\
\hline \multicolumn{11}{|c|}{ Earth's crust } \\
\hline & & 30 & 60 & 6 & 1.2 & 0.9 & 3 & 0.5 & 2.7 & 9.6 \\
\hline \multicolumn{11}{|c|}{ Biosphere } \\
\hline & & 12.0 & 32.0 & 4.5 & 0.6 & 0.6 & 1.9 & 0.5 & 1.9 & 7.6 \\
\hline
\end{tabular}




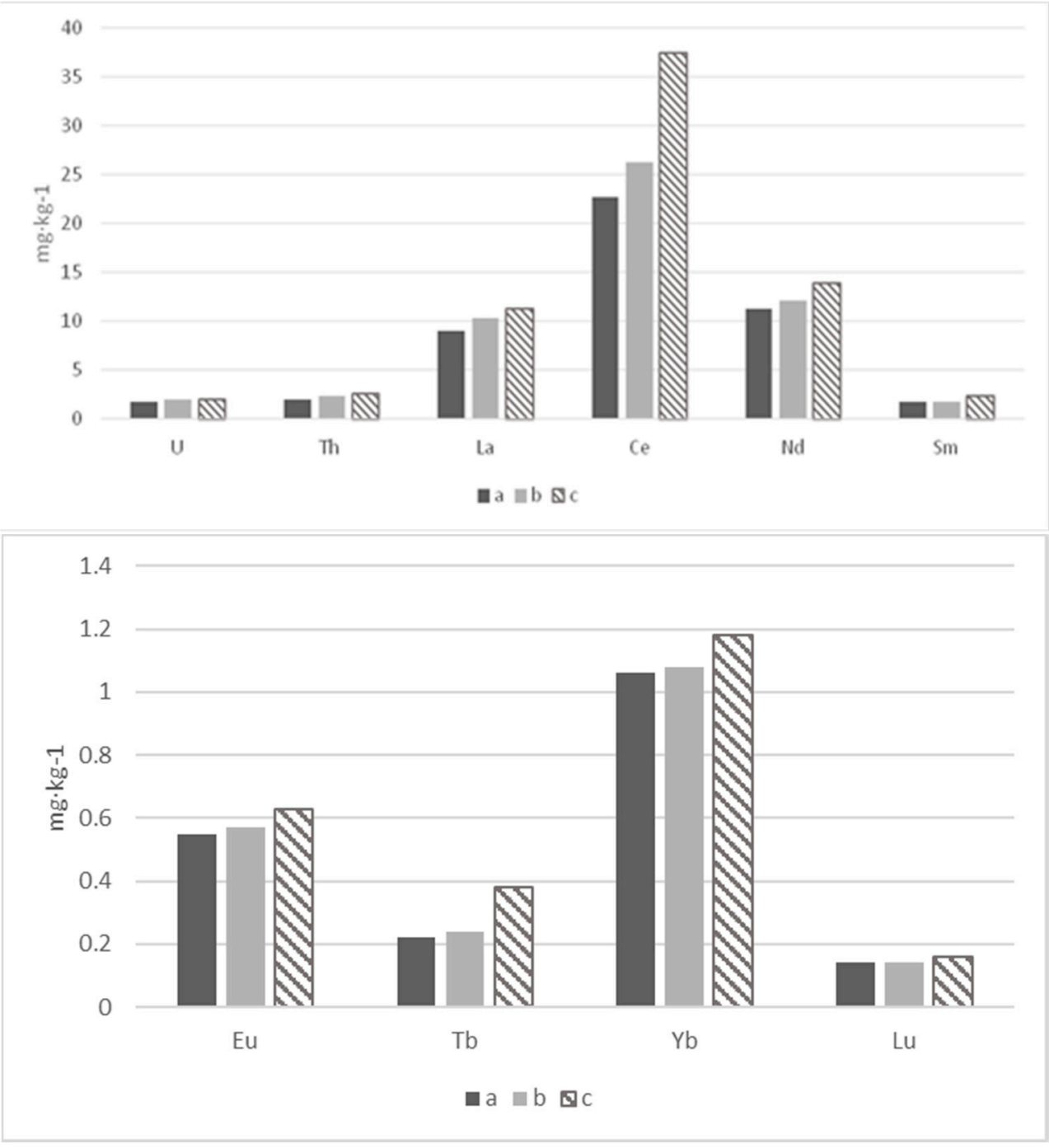

Figure 3. Content of lanthanides, uranium and thorium in soils: (a) paleosols under barrows; (b) paleosols of settlement; (c) recent background soils.

Thus, cerium and lanthanum had the highest content values in soils and paleosols. It was comparable to the content of cobalt, copper, or lead in chernozems in the same region [49]. All studied soils and paleosols contained smaller amounts, not exceeding $2 \mathrm{mg} \cdot \mathrm{kg}^{-1}$ of samarium, europium, terbium, ytterbium, and lutetium. There was a clear trend of these elements' accumulation from ancient times to the recent past (Figure 3).

The studied actinides, uranium, and thorium had an average content not exceeding $2-2.6 \mathrm{mg} \cdot \mathrm{kg}^{-1}$. The uranium content in samples of soils and paleosols from different sections was in the range of $1.8-2.2 \mathrm{mg} \cdot \mathrm{kg}^{-1}$ in the recent soils and 1.1-2.4 in paleosols. For thorium, this range was somewhat wider: $2.43-3.07$ in the first case and 1.55-2.89 in the second.

Regarding the soil row, from paleosols under burial barrows to the recent soils there was a trend of increasing average content of thorium (from 1.97 to $2.64 \mathrm{mg} \cdot \mathrm{kg}^{-1}$ ) and uranium approximately per $20 \mathrm{mg} \cdot \mathrm{kg}^{-1}$.

A comparison of the contents of the individual elements in recent soils of the leached chernozem in the study area with those in the lithosphere [47] and the biosphere [48] showed that these soils could not be considered contaminated by lanthanides, uranium, or thorium as they did not exceed the levels of their content as found in the earth's crust (Table 2). However, the content of some elements was as high as (Eu and U) or even slightly higher (Ce) than their levels in the biosphere (Table 2). 
Therefore, the average content of virtually all the elements in the recent background soil was higher than in the paleosols, either in those buried under barrows or those which experienced anthropogenic transformation from human habitation on the settlement's territory. Although significant differences using Student's $t$-test for the compared objects were not identified, there was a clearly visible negative trend of increased content of the studied elements in recent soil as compared to paleosols isolated between 3.6 and $3.3 \mathrm{ka}$ (Figure 3).

The study results of the element content in humic acid preparations isolated from recent background soils and paleosols of the southern forest-steppe of the Southern Urals are represented in Table 3.

Data analysis shows that cerium and lanthanum had the highest content in preparations of humic acids, i.e., the same elements as in soils. Among the lanthanides, cerium presented in the largest quantities within preparations of humic acids, with an average of 3.4-7.4 $\mathrm{mg}$ per kilogram weight of the preparation. Lanthanum content did not exceed an average of $3.2-3.7 \mathrm{mg} \cdot \mathrm{kg}^{-1}$ in paleosols and was $2.3 \mathrm{mg} \cdot \mathrm{kg}^{-1}$ in the recent leached chernozem.

The average content of samarium, europium, and ytterbium in humic acids was an order less, varying from 0.14 to $0.55 \mathrm{mg} \cdot \mathrm{kg}^{-1}$. Lutetium was two orders less $\left(0.04-0.08 \mathrm{mg} \mathrm{kg}^{-1}\right)$, while terbium was found only in trace amounts in most samples.

Paleosols buried under mounds contained the largest accumulation of lanthanides and lanthanum by humic acids; the fewest in the recent background soil (Figure 4).

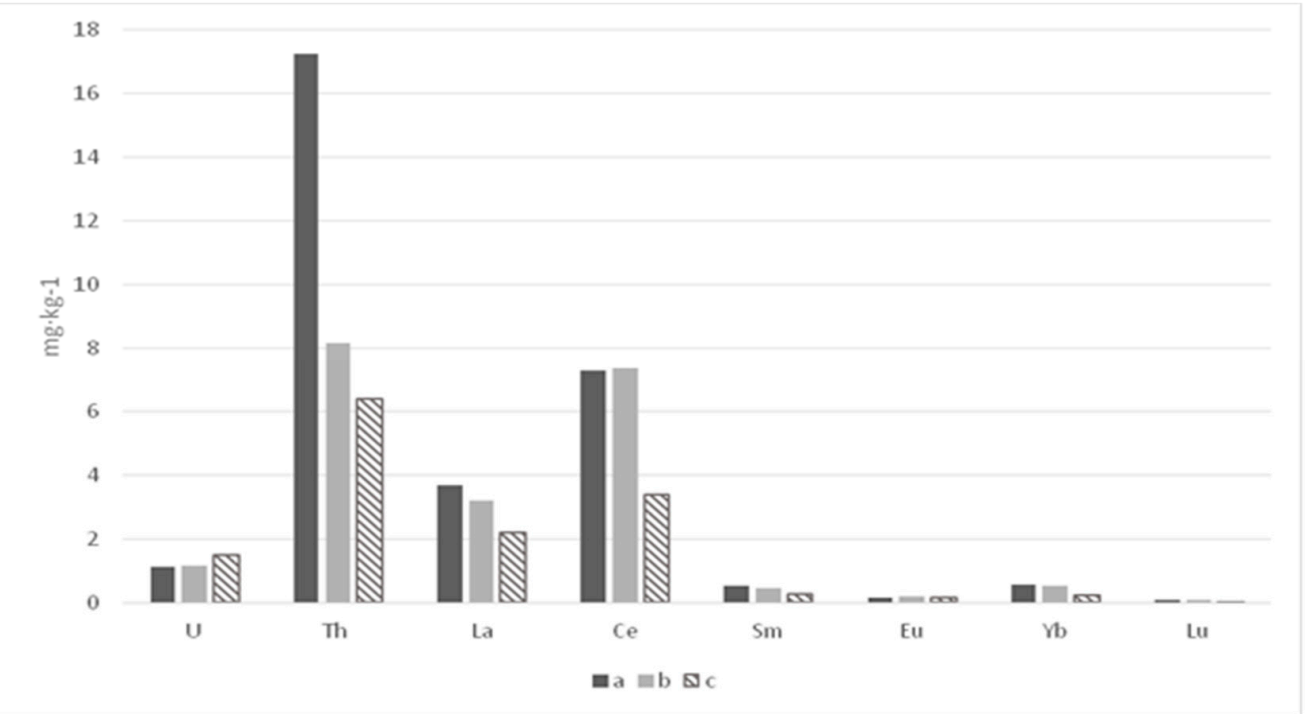

Figure 4. Content of lanthanides, uranium, and thorium in humic acid preparations: (a) paleosols under barrows; (b) paleosols of settlement; (c) recent background soils.

It should be noted that the contents of most elements in humic preparations of paleosols buried under barrows and paleosols of the settlement are close, which means there was virtually no anthropogenic impact on binding by humic acids, lanthanides, and actinides in ancient times.

The highest amount of thorium in the humic acid preparations was found in paleosols buried under mounds, where their content was in the range $11-22 \mathrm{mg} \cdot \mathrm{kg}^{-1}$, averaging more than $17 \mathrm{mg} \cdot \mathrm{kg}^{-1}$ (Table 3), with the uranium content an order less. Humic acids of recent chernozem had accumulated more uranium than both paleosols. Uranium is the exception among the studied elements, as its content in ancient soils is almost the same and substantially higher (more than $30 \mathrm{mg} \cdot \mathrm{kg}^{-1}$ ) than in recent soils. In general, fluctuations of quantitative characteristics of humic acids in their saturation by the elements were small among the objects.

Thus, the average content of $\mathrm{La}, \mathrm{Ce}, \mathrm{Sm}, \mathrm{Eu}, \mathrm{Yb}, \mathrm{Lu}$ and $\mathrm{Th}$ in humic acid preparations of recent soils was lower than in paleosols at the study area with the exception of U, which was higher (Figure 4). 
Table 3. The content of some lanthanides and actinides in the humic acids from humus horizons of paleosols and recent soils of the forest-steppe zone of the Southern Urals, $\mathrm{mg} \cdot \mathrm{kg}^{-1}$.

\begin{tabular}{|c|c|c|c|c|c|c|c|c|c|c|}
\hline Section & Depth (cm) & La & $\mathrm{Ce}$ & Sm & $\mathbf{E u}$ & $\mathrm{Tb}^{*}$ & $\mathbf{Y b}$ & Lu & $\mathbf{U}$ & Th \\
\hline \multicolumn{11}{|c|}{ Recent background soils } \\
\hline \multirow[t]{3}{*}{$1-03$} & $0-2$ & 2.0 & 3.5 & 0.26 & 0.12 & $<0.01$ & 0.25 & 0.04 & 1.30 & 5.2 \\
\hline & $2-10$ & 2.1 & 4.8 & 0.32 & 0.14 & $<0.01$ & 0.28 & 0.05 & 1.27 & 6.9 \\
\hline & $10-15$ & 2.1 & 3.9 & 0.40 & 0.15 & $<0.01$ & 0.28 & 0.05 & 1.31 & 7.9 \\
\hline \multirow[t]{2}{*}{$3-03$} & $2-7$ & 2.2 & 3.0 & 0.26 & 0.13 & $<0.01$ & 0.26 & 0.03 & 1.31 & 5.9 \\
\hline & $7-12$ & 2.7 & 3.0 & 0.20 & 0.20 & $<0.01$ & 0.18 & 0.05 & 1.36 & 8.7 \\
\hline $8-03$ & $0-2$ & 1.8 & 2.2 & 0.18 & 0.11 & $<0.01$ & 0.21 & 0.03 & 2.10 & 3.7 \\
\hline \multicolumn{2}{|l|}{ Average $(n=6)$} & $2.2 \pm 0.3$ & $3.4 \pm 0.9$ & $0.27 \pm 0.07$ & $0.14 \pm 0.03$ & - & $0.24 \pm 0.04$ & $0.04 \pm 0.001$ & $1.48 \pm 0.28$ & $6.4 \pm 1.7$ \\
\hline \multicolumn{11}{|c|}{ Paleosols under barrows } \\
\hline \multirow[t]{3}{*}{3} & $0-7$ & 3.2 & 7.4 & 0.51 & 0.12 & $<0.01$ & 0.62 & 0.09 & 0.55 & 9.4 \\
\hline & $7-14$ & 8.2 & 16.0 & 1.09 & 0.23 & $<0.01$ & 1.03 & 0.17 & 1.51 & 21.0 \\
\hline & $14-21$ & 4.4 & 12.3 & 0.65 & 0.14 & 0.08 & 0.97 & 0.12 & 1.42 & 12.6 \\
\hline \multirow[t]{3}{*}{4} & $0-7$ & 4.1 & 8.8 & 0.63 & 0.15 & $<0.01$ & 0.60 & 0.09 & 0.85 & 20.7 \\
\hline & $7-14$ & 4.0 & 8.8 & 0.50 & 0.16 & $<0.01$ & 0.64 & 0.10 & 0.98 & 14.2 \\
\hline & $14-23$ & 3.0 & 6.3 & 0.43 & 0.15 & $<0.01$ & 0.52 & 0.09 & 0.74 & 10.9 \\
\hline \multirow[t]{3}{*}{6} & $0-7$ & 2.4 & 4.8 & 0.40 & 0.13 & $<0.01$ & 0.31 & 0.05 & 0.91 & 19.3 \\
\hline & $7-14$ & 3.3 & 6.9 & 0.46 & 0.14 & 0.03 & 0.56 & 0.08 & 1.05 & 20.4 \\
\hline & $14-21$ & 2.9 & 6.2 & 0.44 & 0.12 & 0.07 & 0.44 & 0.07 & 1.09 & 19.3 \\
\hline \multirow[t]{2}{*}{7} & $0-7$ & 3.0 & 5.3 & 0.46 & 0.12 & 0.09 & 0.39 & 0.07 & 1.41 & 23.3 \\
\hline & $7-14$ & 3.4 & 6.3 & 0.47 & 0.12 & 0.05 & 0.44 & 0.06 & 1.37 & 17.5 \\
\hline \multirow[t]{3}{*}{8} & $0-7$ & 3.6 & 6.5 & 0.41 & 0.12 & $<0.01$ & 0.42 & 0.07 & 1.19 & 17.3 \\
\hline & $7-14$ & 3.5 & 7.2 & 0.44 & 0.14 & $<0.01$ & 0.52 & 0.07 & 1.15 & 18.3 \\
\hline & $14-22$ & 3.5 & 4.1 & 0.47 & 0.13 & $<0.01$ & 0.53 & 0.10 & 1.10 & 21.9 \\
\hline \multirow[t]{3}{*}{10} & $0-7$ & 3.5 & 6.9 & 0.46 & 0.14 & $<0.01$ & 0.39 & 0.05 & 1.48 & 14.3 \\
\hline & $7-14$ & 2.9 & 3.2 & 0.45 & 0.13 & $<0.01$ & 0.41 & 0.06 & 1.04 & 16.9 \\
\hline & $14-21$ & 3.3 & 6.6 & 0.50 & 0.09 & $<0.01$ & 0.54 & 0.07 & 1.00 & 16.0 \\
\hline Average $(n=17)$ & & $3.7 \pm 1.3$ & $7.3 \pm 3.0$ & $0.52 \pm 0.16$ & $0.14 \pm 0.03$ & - & $0.55 \pm 0.19$ & $0.08 \pm 0.03$ & $1.11 \pm 0.27$ & $17.3 \pm 3.93$ \\
\hline \multicolumn{11}{|c|}{ Paleosols of settlement } \\
\hline G3-1 & $0-10$ & 1.2 & 3.6 & 0.16 & 0.18 & $<0.01$ & 0.16 & 0.04 & 1.64 & 4.5 \\
\hline G3-2 & $0-12$ & 2.6 & 5.6 & 0.38 & 0.11 & $<0.01$ & 0.39 & 0.07 & 0.92 & 7.6 \\
\hline G4-1 & $0-11$ & 3.0 & 6.7 & 0.09 & 0.16 & 0.05 & 0.45 & 0.08 & 0.78 & 12.7 \\
\hline
\end{tabular}


Table 3. Cont

\begin{tabular}{|c|c|c|c|c|c|c|c|c|c|c|}
\hline Section & Depth (cm) & La & $\mathrm{Ce}$ & Sm & Eu & $\mathrm{Tb}^{*}$ & $\mathbf{Y b}$ & Lu & $\mathbf{U}$ & Th \\
\hline \multicolumn{11}{|c|}{ Recent background soils } \\
\hline G4-2 & $0-11$ & 2.2 & 4.5 & 0.29 & 0.14 & $<0.01$ & 0.33 & 0.06 & 1.36 & 2.1 \\
\hline G6-1 & $0-10$ & 0.7 & 3.3 & 0.10 & 0.16 & $<0.01$ & 0.12 & 0.02 & 1.97 & 1.5 \\
\hline G6-2 & $0-12$ & 2.2 & 4.7 & 0.33 & $<0.05$ & $<0.01$ & 0.11 & $<0.01$ & 0.40 & 3.4 \\
\hline G6-3 & $0-11$ & 3.6 & 9.5 & 0.58 & 0.14 & $<0.01$ & 0.54 & 0.06 & 0.76 & 7.5 \\
\hline B6-1 & $0-10$ & 4.5 & 10.7 & 0.62 & 0.16 & $<0.01$ & 0.90 & 0.10 & 0.94 & 15.1 \\
\hline B6-2 & $0-12$ & 6.3 & 11.9 & 0.95 & 0.25 & $<0.01$ & 0.99 & 0.16 & 1.14 & 15.8 \\
\hline B6-3 & $0-11$ & 5.6 & 12.9 & 0.79 & 0.19 & $<0.01$ & 1.08 & 0.14 & 1.51 & 11.6 \\
\hline Average $(n=10)$ & & $3.2 \pm 1.8$ & $7.4 \pm 3.6$ & $0.43 \pm 0.30$ & $0.17 \pm 0.05$ & - & $0.51 \pm 0.36$ & $0.08 \pm 0.04$ & $1.14 \pm 0.48$ & $8.18 \pm 5.34$ \\
\hline
\end{tabular}

* due to the content of the element in the majority of HA preparations in trace amounts, the average value is not provided. 
The calculation of the studied elements' direct content in humic acids of soils and paleosols and the determination of their share in the total pool of natural objects under investigation was based on the average data (Table 4).

Table 4. The average content of some lanthanides and actinides in the humic acids recalculated to soil and paleosol carbon and HA contribution in their pool.

\begin{tabular}{|c|c|c|c|c|c|c|c|c|}
\hline \multirow{2}{*}{ Parameters } & \multicolumn{8}{|c|}{ Elements } \\
\hline & La & $\mathrm{Ce}$ & Sm & Eu & $\mathbf{Y b}$ & Lu & $\mathbf{U}$ & Th \\
\hline \multicolumn{9}{|c|}{ Paleosols under barrows } \\
\hline Mass, $\mathrm{mg} / \mathrm{kg}^{-1}$ & 0.0210 & 0.0420 & 0.0030 & 0.0008 & 0.0032 & 0.0005 & 0.0064 & 0.1000 \\
\hline Share, $\%$ & 0.23 & 0.19 & 0.17 & 0.15 & 0.30 & 0.29 & 0.36 & 5.08 \\
\hline \multicolumn{9}{|c|}{ Paleosols of settlement } \\
\hline Mass, $\mathrm{mg} / \mathrm{kg}^{-1}$ & 0.0227 & 0.0522 & 0.0030 & 0.0012 & 0.0036 & 0.0005 & 0.0080 & 0.0580 \\
\hline Share, $\%$ & 0.22 & 0.20 & 0.17 & 0.21 & 0.34 & 0.41 & 0.41 & 2.48 \\
\hline \multicolumn{9}{|c|}{ Recent background soils } \\
\hline Mass, $\mathrm{mg} / \mathrm{kg}^{-1}$ & 0.0682 & 0.1054 & 0.0084 & 0.0043 & 0.0074 & 0.0012 & 0.0459 & 0.1984 \\
\hline Share, $\%$ & 0.60 & 0.28 & 0.35 & 0.69 & 0.63 & 0.78 & 2.34 & 7.51 \\
\hline
\end{tabular}

The results show that the highest shares of all the elements are found in recent background soils; the lowest are in the soil buried under barrows of about 3.6 ka (Figure 5).

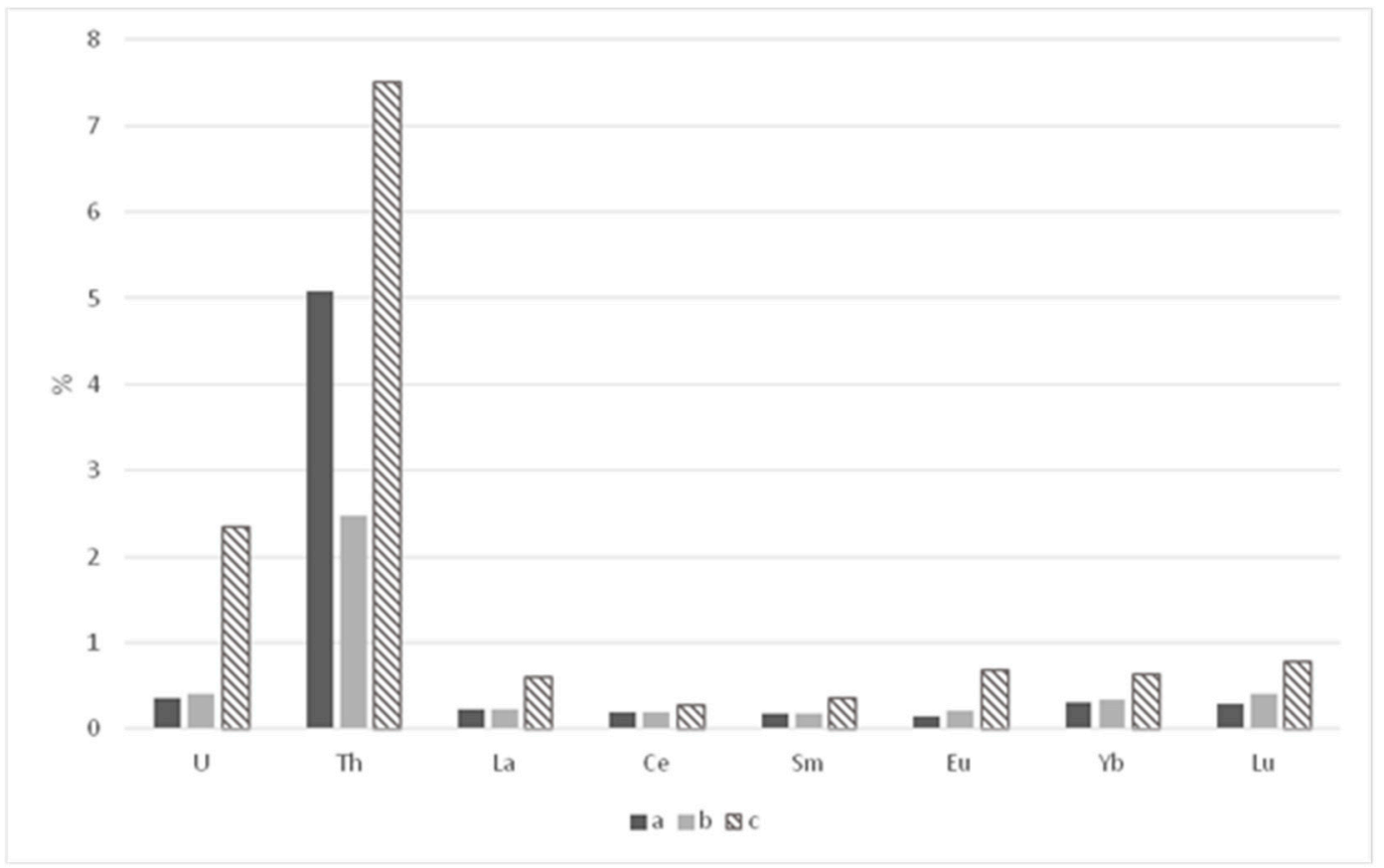

Figure 5. Humic acid contribution in the soil pool of lanthanides, uranium and thorium: (a) paleosols under barrows; (b) paleosols of settlement; (c) recent background soils.

The highest percentage of all investigated elements in humic acids relative to their content was found in the paleosols buried under the mound $(6.8 \%)$, compared to $4.4 \%$ found in the anthropogenically transformed settlement paleosols. This contrasts to the $13.2 \%$ found in recent soil in the territory including, respectively, $3.3 \%$ and $9.9 \%$ of lanthanides and actinides.

Thus, the largest share of lanthanides and actinides is contained in recent soils. 


\section{Conclusions}

This study contains a comparative analysis of the actual content of lanthanides and actinides in recent soils and paleosols and the humic acids isolated from them. Though similar levels of the element accumulation were identified both in paleosols isolated from the active medium 3.6 and $3.3 \mathrm{ka}$ and in the recent background soils, the tendency of increased rare metal content in the series "the buried paleosols-man-modified paleosols of settlement-recent background soils" was revealed. The content of the studied elements in paleosols buried under barrows should be a starting point in identifying contamination processes over time. The lowest content of $\mathrm{La}, \mathrm{Ce}, \mathrm{Sm}, \mathrm{Eu}, \mathrm{Yb}, \mathrm{Lu}$, and Th was detected in preparations of humic acids from recent background soils. The content of most elements in humic acids of paleosols buried under barrows and paleosols from settlements of comparative ages was similar. This indicates the virtual absence of anthropogenic impact on binding lanthanides and actinides by humic acids in ancient times.

We proposed a method of element content recalculation which considers their amounts in separate humic acid preparations as well as the presence of humic acids in the soil. The method also incorporated a determination of the share in the accumulation and deposit of lanthanides and actinides by that component of humic substances. Humic acids play the most significant role in the total pool of lanthanides and actinides in recent soils among studied objects.

Acknowledgments: The part of the work was carried out in the Ural Federal University and was supported by the Competitiveness Enhancement Program (SC 02.A03.21.0006) and by RFBR according to the research project No. 18-04-00714. The authors thank the anonymous reviewers for the helpful comments that improved the paper.

Author Contributions: Dmitry Zdanovich helped in dating and sampling unique paleosols, Olga Nekrasova got soil and humic acid characteristics, Leonid Rikhvanov determined the content of soil and humic acid lanthanids and actinides and Maria Dergacheva interpreted the data and prepared the paper. All authors read and approved the final manuscript.

Conflicts of Interest: The authors declare no conflict of interest.

\section{References}

1. Dergacheva, M.I. Ecological functions of soil humus. Eurasian Soil Sci. 2001, 34 (Suppl. 1), 100-105.

2. Bleam, W. Natural Organic Matter. In Soil and Environmental Chemistry, 2nd ed.; Academic Press: Cambridge, MA, USA, 2017; Chapter 7; pp. 333-384.

3. Terbouche, A.; Ramdane-Terbouche, C.A.; Hauchard, D.; Djebbar, S. Evaluation of adsorption capacities of humic acids extracted from Algerian soil on polyaniline for application to remove pollutants such as Cd(II), Zn(II) and Ni(II) and characterization with cavity microelectrode. J. Environ. Sci. 2011, 23, 1095-1103. [CrossRef]

4. Terbouche, A.; Djebbar, S.; Benali-Baitich, O.; Hauchard, D. Complexation Study of Humic Acids Extracted from Forest and Sahara Soils with Zinc(II) and Cadmium(II) by Differential Pulse Anodic Stripping Voltammetry (DPASV) and Conductimetric Methods. Water Air Soil Pollut. 2011, 216, 679-691. [CrossRef]

5. Kabata-Pendias, A. Trace Elements in Soils and Plants; Taylor and Francis Group, LLC: Oxfordshire, UK, 2011; 505 .

6. Motuzova, G.V.; Makarichev, I.P.; Dergham, H.M.; Stepanov, A.A.; Barsova, N.U. Soil Organic Matter and Its Interactions with Metals: Processes, Factors, Ecological Significance; Nova Science Publishers, Inc.: New York, NY, USA, 2012; 129p.

7. Shaker, M.A.; Albishri, H.M. Dynamics and thermodynamics of toxic metals adsorption onto soil-extracted humic acid. Chemosphere 2014, 111, 587-595. [CrossRef] [PubMed]

8. Stepanova, M.D. Microelements in Organic Matter of Soils; Izd Nauka: Novosibirsk, Russian, 1976; 105p. (In Russian)

9. Minkina, T.M.; Motuzova, G.A.; Nazarenko, O.G. Interaction of heavy metals with organic matter of an ordinary chernozem. Eurasian Soil Sci. 2006, 39, 720-726. [CrossRef]

10. Datta, R.; Quispe, M.A.; Sarkar, D. Greenhouse study on the phytoremediation potential of vetiver grass, Chrysopogon zizanioides L., in arsenic-contaminated soils. Bull. Environ. Contam. Toxicol. 2011, 86, 124-128. [CrossRef] [PubMed] 
11. Clemente, R.; Pilar, M. Bernal Fractionation of heavy metals and distribution of organic carbon in two contaminated soils amended with humic acids. Chemosphere 2006, 64, 1264-1273. [CrossRef] [PubMed]

12. Wang, Y.Q.; Fan, Q.H.; Li, P.; Zheng, X.B.; Xu, J.Z.; Jin, Y.R.; Wu, W.S. The sorption of Eu(III) on calcareous soil: Effects of $\mathrm{pH}$, ionic strength, temperature, foreign ions and humic acid. J. Radioanal. Nucl. Chem. 2011, 287, 231-237. [CrossRef]

13. Evangelou, M.W.H.; Daghan, H.; Schaeffer, A. The influence of humic acids on the phytoextraction of cadmium from soil. Chemosphere 2004, 57, 207-213. [CrossRef] [PubMed]

14. Zhang, Y.; Yang, X.; Zhang, S.; Tian, Y.; Guo, W.; Wang, J. The influence of humic acids on the accumulation of lead $(\mathrm{Pb})$ and cadmium $(\mathrm{Cd})$ in tobacco leaves grown in different soils. J. Soil Sci. Plant Nutr. 2013, 13, 43-53.

15. Vargas, C.; Pérez-Esteban, J.; Escolástico, C.; Masaguer, A.; Moliner, A. Phytoremediation of Cu and Zn by vetiver grass in mine soils amended with humic acids. Environ. Sci. Pollut. Res. 2016, 23, 13521-13530. [CrossRef] [PubMed]

16. Perkins, R.W.; Thomas, C.W. Worldwide fallout. In Transuranic Elements in the Environment; Hanson, W.C., Ed.; Tech. Inf. Center US Department of Energy: Washington, DC, USA, 1980; pp. 53-82.

17. Wang, F.; Banerjee, D.; Liu, Y.; Chen, X.; Liu, X. Upconversion nanoparticles in biological labeling, imaging, and therapy. Analyst 2010, 135, 1839-1854. [CrossRef] [PubMed]

18. Lin, M.; Zhao, Y.; Wang, S.; Liu, M.; Duan, Z.; Chen, Y.; Li, F.; Xu, F.; Lu, T. Recent advances in synthesis and surface modification of lanthanide-doped upconversion nanoparticles for biomedical applications. Biotechnol. Adv. 2012, 30, 1551-1556. [CrossRef] [PubMed]

19. Chen, G.; Yang, C.; Prasad, P.N. Nanophotonics and Nanochemistry: Controlling the Excitation Dynamics for Frequency Up- and Down-Conversion in Lanthanide-Doped Nanoparticles. Acc. Chem. Res. 2013, 46, 1474-1486. [CrossRef] [PubMed]

20. Zheng, W.; Huang, P.; Tu, D.; Ma, E.; Zhuab, H.; Chen, X. Lanthanide-doped upconversion nano-bioprobes: Electronic structures, optical properties, and biodetection. Chem. Soc. Rev. 2015, 44, 1379-1415. [CrossRef] [PubMed]

21. Perez-Lopez, R.; Alvarey-Valero, A.M.; Nieto, J.M. Changes in mobility of toxic elements during the production of phosphoric acid in the fertilizer industry of Huelve (SW Spain) and environmental impact of phosphogypsum wastes. J. Hazard. Mater. 2007, 148, 745-750. [CrossRef] [PubMed]

22. Glasser, G.; Jones, R. Phosphate Rocks Fertilizer: Toxic Metals, radiaTion Hazards, Fluoride and Organic Growing. 2008. Available online: http:/ / www.npwa.freeserve.co.uk/organic.html (accessed on 20 August 2009).

23. Colman, R.; Alecsander, B. The effects of lantanides and actinides on biood coagulation. J. Clin. Investig. 1964, 43, 720-727. [CrossRef] [PubMed]

24. Palasz, A.; Czekaj, P. Toxicological and cytophysiological aspects of lanthanides action. Acta Biochim. Pol. 2000, 47, 1107-1114. [PubMed]

25. Ali, M.; Kumar, A.; Kumar, M.; Pandey, B.N. The interaction of human serum albumin with selected lanthanide and actinide ions: Binding affinities, protein unfolding and conformational changes. Biochimie 2016, 123, 117-129. [CrossRef] [PubMed]

26. Soler-Rovira, P.; Madejyn, E.; Madejyn, P.; Plaza, C. In situ remediation of metal-contaminated soils with organic amendments: Role of humic acids in copper bioavailability. Chemosphere 2010, 79, 844-849. [CrossRef] [PubMed]

27. Arancon, N.Q.; Edwards, C.A.; Atiyeh, R.; Metzger, J.D. Effects of vermicomposts produced from food waste on the growth and yields of greenhouse peppers. Bioresour. Technol. 2004, 93, 139-144. [CrossRef] [PubMed]

28. Chen, Y.; De Nobili, M.; Aviad, T. Stimulatory effects of humic substances onplant growth. In Soil Organic Matter in Sustainable Agriculture; Magdoff, F., Weil, R.R., Eds.; CRC Press: Boca Raton, FL, USA, 2004.

29. Nardi, S.; Carletti, P.; Pizzeghello, D.; Muscolo, A. Biological activities of humic substances. In Biophysico-Chemical Processes Involving Natural Nonliving Organic Matter in Environmental Systems; Part 1: Fundamentals and Impact of Mineral-organic-Biota Interactions on the Formation, Transformation, Turnover, and Storage of Natural Nonliving Organic Matter (NOM); Senesi, N., Xing, B., Huang, P.M., Eds.; Wiley: Hoboken, NJ, USA, 2009; Volume 2, pp. 305-340.

30. Canellas, L.P.; Olivares, F.L. Physiological responses to humic substances asplant growth promoter. Chem. Biol. Technol. Agric. 2014, 1, 1-11. [CrossRef] 
31. Hernandez, O.; Calderín, A.; Huelva, R.; Martínez-Balmori, D.; Guridi, F.; Aguiar, N.; Olivares, F.; Pasqualoto, L.; Canellas, L.P. Humic substances from vermicompost enhance urban lettuce production. Agron. Sustain. Dev. 2015, 35, 225-232. [CrossRef]

32. Sycheva, S.A. Soil-geomorphological aspects of the formation of the cultural layer of the ancient settlements. Pochvovedenie 1994, 3, 28-33. (In Russian)

33. Sycheva, S.A.; Leonova, N.B.; Aleksandrovsky, A.L. A Guide to the Study of Paleoecology of Cultural Layers of Ancient Settlements; MSU: Moscow, Russian, 2000; 88p. (In Russian)

34. AST. National Soil Atlas of the Russian Federation; AST: Moscow, Russian, 2011; 632p. (In Russian)

35. Climate-Data. Plast. Available online: http:/ / en.climate-data.org/location/32588/ (accessed on 7 December 2017).

36. Kulikov, P.V. Vascular Plants of the Chelyabinsk Region; UrB RAS: Yekaterinburg, Russian, 2010; 969p. (In Russian)

37. World Reference Base for Soil Resources. International Soil Classification System for Naming Soils and Creating Legends for Soil Maps; Food and Agriculture Organization of the United Nations: Rome, Italy, 2014; 181p.

38. Kupriyanova, E.V.; Zdanovich, D.G. Ancient of the Forest-Steppe Trans-Urals; Burial Stepnoe: Chelyabinsk, Russia, 2008; 196p. (In Russian)

39. Zdanovich, G.B.; Batanina, I.M. Arkaim-The Country of Cities; Arkaim: Chelyabinsk, Russia, 2007; 260p. (In Russian)

40. Dergacheva, M.I.; Nekrasova, O.A.; Okoneshnikova, M.V.; Vasil'eva, D.I.; Gavrilov, D.A.; Ochur, K.O.; Ondar, E.E. Ratio of Elements in Humic Acids as a Source of Informationon the Environment of Soil Formation. Contemp. Probl. Ecol. 2012, 5, 497-504. [CrossRef]

41. Dergacheva, M.I.; Nekrasova, O.A.; Vasil'eva, D.I.; Fadeeva, V.P. Humic acid elemental composition of different formation condition virgin chernozems. Bull. Orenbg. State Univ. 2012, 10, 90-96. (In Russian)

42. Dergacheva, M.I. Archaeological Pedology; Siberian Branch of Russian Academy of Science: Novosibirsk, Russian, 1997; 228p. (In Russian)

43. Dergacheva, M.I. Pedohumic method in paleoenvironmental reconstructions: An example from Middle Siberia. Quat. Int. 2003, 106-107, 73-78. [CrossRef]

44. Dergacheva, M.; Fedeneva, I.; Bazhina, N.; Nekrasova, O.; Zenin, V. Shestakovo site of Western Siberia (Russia): Pedogenic features, humic substances and paleoenvironment reconstructions for last 20-25 ka. Quat. Int. 2015. [CrossRef]

45. Tyurin, I.V. Soil Organic Matter and Its Role in Fertility; Akademii Nauk SSSR: Moskow, Russian, 1965; 108p. (In Russian)

46. Ponomareva, V.V.; Plotnikova, T.A. The methodology and the results of fractionation of chernozem humus. J. Soil Sci. 1968, 11, 104-117. (In Russian)

47. Taylor, S.R. Abundance of chemical elements in the continental crust-A new table. Geochim. Cosmochim. Acta 1964, 28, 1273-1285. [CrossRef]

48. Glazovskaya, M.A.; Kasimov, N.S.; Teplitskaya, T.A. Landscape-Geochemical Bases of Background Monitoring of the Environment; Nauka: Moscow, Russian, 1989; 264p. (In Russian)

49. Nekrasova, O.A.; Dergacheva, M.I. The content of trace elements in chernozem ordinary and their humic acids. Bull. Tomsk State Univ. Biol. 2011, 4, 7-16. (In Russian)

(C) 2018 by the authors. Licensee MDPI, Basel, Switzerland. This article is an open access article distributed under the terms and conditions of the Creative Commons Attribution (CC BY) license (http://creativecommons.org/licenses/by/4.0/). 